\title{
MIGRANTS REMITTANCES: MICROECONOMIC AND MACROECONOMIC CONTEXTS
}

\author{
Andrej Př́ivara \\ University of Economics in Bratislava, Slovak Republic
}

Global remittances flow has been rising considerably over the last decade. Their share in GDP reaches several tens of percent in some (especially developing) countries. That is why their impact on the country of the migrant's origin has become a subject of controversial debate in the scientific community. This chapter provides a synthesis of views that have crystallized as part of an ongoing academic debate on remittance determinants and their impact on recipient countries. We aim to analyze the fundamental scientific opinions published on this topic and to outline possible directions for future research on migrant remittances. The chapter analyzes individual determinants as well as remittance effects on two levels: microeconomic and macroeconomic ones. The analysis concludes that remittances are an important source of external financing for the economies of developing countries. Nonetheless, they cannot be considered as a panacea for economic backwardness.

Keywords: migration; remittances; migration policy; EU; V-4

\section{Instruments}

Remittances are one of the consequences from international migration of the labour force (Deskar-Škrbić et al., 2018; Škuflić \& Vučković, 2018). They represent the cash flow sent by migrants to their countries of origin. The International Monetary Fund (IMF) defines these transfers as: "The household income generated from the reserves saved abroad, usually in the course of a temporary or permanent movement of people" (IMF, 2009, p. 272).

In the course of the last years, the research on the issues related to remittances has intensified. International organizations, as well as scientific community, discuss in particular the problems related to definition of the determinants of remittances, the ways of realization of these money transfers, as well as economic impact of the related financial operations on the country of migrant origin.

The raised interest in the issue of remittances is undeniably related to the enormous development potential hidden in them. One of their advantages is that they represent a more stable capital resource as compared to the two other international cash flows: foreign direct investments (FDI) and development aid. Unlike FDI, whose amount increases in upward fluctuations of the economic cycle and decreases during a recession, money transfers from

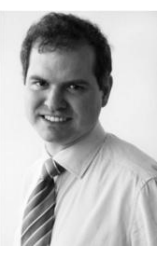

\footnotetext{
Andrej Př́ívara

Ing., PhD, work as Assistant Professor in Department of Social Development and Labour in University of economics, Bratislava, Slovak Republic.

Science interests: European social system, social psychology, organizational behavior and management, international labor market and transboundary movement of labor forces, problems of migrants socialization

E-mail: andrej.privara@euba.sk
} 


\section{MIGRANTS REMITTANCES: MICROECONOMIC}

migrants are subject to economic conjuncture to a significantly smaller degree. Stronger resistance of remittances to cyclical fluctuations in migrants' host countries can be accounted for by the protection of income in the times of economic recession by the mechanisms protecting employees (e.g., unemployment benefit).

The ambition of our chapter is to contribute to the ongoing discussion on the determinants of remittances and their impact on the countries receiving them. Its aim is the analysis of academic discussion based on the substantial number of scientific works published on the topic concerned and also suggesting possible directions for future research.

\section{Economic Effects of Remittances}

The impact of remittances on the country of migrant's origin can be scrutinized on two levels: microeconomic and macroeconomic. The study of microeconomic effects focuses in particular on the immediate impact of remittances on income distribution, poverty reduction and on household economic activities. This research involves a great number of case studies which provide a number of interesting empirical results. However, their specific character does not enable a generalisation. Contribution of macroeconomic effects cannot help with eliminating this barrier completely, but it can, however, lead to an international comparison of results.

\section{Microeconomic impact of remittances}

Case studies on the influence of finances sent by migrants to the country of their origin on the poverty rate in these countries usually agree that since remittances increase the available household income of receivers, they also have a positive impact on poverty reduction. With regard to quantification of this impact, differences in the results reached may be accounted for by specifications of the studied sample. As an example, we might mention a study by Richard H. Adams and John Page. These two authors created the panel of 71 developing countries on which they tested a hypothesis that the countries with higher migration rate and more of remittance receipts report relatively lower poverty rates. They reached the conclusion that an increase of $10 \%$ in the level of remittances per inhabitant contributes to a decrease in poverty by 3,5\% (Adams \& Page, 2005).

A study by the IMF conducted in 2005 scrutinizes this issue on the sample of 101 countries. According to the results of this study, an increase of remittances rate within GDP by $2,5 \%$ is connected with a decrease of poverty rate by $0,5 \%$.

Gupta, Patillo and Wagh discovered that an increase of remittance flows by $10 \%$, under the conditions of the Sub-Saharan Africa, is connected with a decrease of the poverty rate by $1 \%$ (Gupta et al., 2007).

The study of Fajnzylber and Lopez on the countries of Latin America also reached the conclusion that remittances have a direct effect on households' income (Fajnzylbel \& Lopez, 2008).

Conclusions reached by different authors significantly differ with respect to the impact of remittances on income inequality. Lisa Chauvet and Sandrine Mesplé-Soms, for instance, prove in their article that foreign direct investments increase income inequalities within the country, whereas money transfers realised by migrants tend to decrease them (Chauvet \& Mesplé-Soms, 2007). 
On the other hand, according to Azam and Gubert (2005), the impact of remittances on income inequality is unclear. These authors also warn that it is necessary to take the differences occurring in different time periods into account. According to them, remittances trigger, in the short term, an increase of income inequalities between families who are capable of sending a migrant abroad and consequently receive certain money flows, and the other families who do not have such an opportunity. In the long term, however, emigration costs decrease (especially thanks to networking), which enables less wealthy families also send their relatives abroad.

Docquier and Rapoport underline the necessity to take income inequality in the introductory period of time into account. They prove that in case of a significant introductory income inequality, remittances incite its further regression. However, this effect does not occur if the introductory income inequality rate is low (Docquier \& Rapoport, 2003).

A very motivating article was published by Christian Ebeke and Maelan Le Goff, who studies the impact of transfers on income inequality on the sample of 80 developing countries in the course of a relatively longer period of time (1970-2000). The conclusion of their analysis was that remittance transfers induce a decrease in income inequality in the countries with relatively high income per inhabitant, in the countries which export low-qualified workforce and in the countries characterized by low mobility expenses (Ebeke \& le Goff, 2010).

Different case studies confirm the direct impact of remittances on economic activity of the sending household. Amuedo-Dorantes and Pozo, whose research was aimed at Mexico, found out that women, in rural communities in particular, lower their labour supply in proportion to received remittances (Amuedo-Dorantes \& Pozo, 2006).

Other case studies prove the existence of an inverse relationship between money transfers from emigrants and labour supply of the receivers' households. As a good example, we might mention the case study by Görlicha and al. who investigated this correlation on the case of Moldova (Görlich and al., 2007), or Konica and Filer in the case of Albania (Konica \& Filer, 2009).

\section{Macroeconomic impacts of remittances}

Out of all of the macroeconomic impacts of remittances on the country of migrant's origin, it is necessary to mention particularly their direct effect on the amount of investments. Finances sent by migrants to the country of their origin can play a significant role in the incorporation and financing of small businesses, as was proved, for instance, by the study by Woodruff and Zeneto, analysing the situation of multiple sectors in Mexico (Woodruff \& Zeneto, 2001).

Another substantial macroeconomic effect of remittances on the country of migrant's origin is the rise of aggregate demand. Notwithstanding, whether it is the rise in demand of consumption or investment of goods, it generates (in the sense of the Keynesian investment multiplier) additional incomes. If production capacities in the country of migrant's origin are not used to their full potential, its impact on the growth of GDP and employment is positive. Multiple empirical research agree that multiplier effects may incite a significant growth in GDP. As an example, we might mention Ratha's study which claims that each "migradollar" spent in Mexico increases its GDP by 2.69 USD (if the remittance recipients are city 


\section{MIGRANTS REMITTANCES: MICROECONOMIC}

households) or even by 3.17 USD (if the remittance recipients are rural households) (Ratha, 2003).

Since remittances represent an addition to receiving side's balance of payments, they can play a major role in deficit reduction. Their advantage, in contrast to other monetary flows (such as development aid, FDI or foreign loans) is that they are not directly connected to specific investment projects with a necessity of significant imports. Moreover, they are characterized by a much more stable source of foreign exchange than other capital flows (Buch \& Kuckulenz, 2004).

In case of an excessive inflow of finances from abroad, however, other effects might arise as well, which are, unfortunately, negative. Consequently, competitiveness of the receiving country may decrease both at foreign markets (as exported products become more expensive) and domestically (imported goods become cheaper). This situation may also induce the so-called "Dutch disease": remittances cause deformations in the production structure and in relative prices (Bourdet \& Falk, 2006). The rise in the unemployment rate and, consequently, of emigration can be the secondary consequences of this "Dutch disease". However, negative consequences mentioned here do not have to arise if the imported, cheaper production facilities increase productivity of the local labour as well as competitiveness of domestic producers.

\section{Main sources and directions of remittances flow}

The main vectors of remittance flows are from economically developed countries to developing countries. The "Rich West" opens the door to people from the "Third World" who are willing to meet the demands of developed countries by their work. The result of such "cooperation" is to improve the living situation of migrants and their families, while rich countries indirectly help with the development of the "Third World" countries through remittances.

The biggest source of remittances in terms of economic strength, prosperity, state wealth are rich, economically developed states that are able to receive large numbers of migrants due to their "unlimited" financial capacity. According to the long-term global analysis, the share of developed countries in the total volume of remittances is up to $66 \%$. In particular, the largest contributor is the USA, this country acconts for $28 \%$ of the total remittance flows (35.4 bln USD) with the trend set to grow further. Saudi Arabia goes the second, with $12 \%$, or 14.9 bln USD. Despite the fact that this country is very popular among migrants, the volume of remittances sent from it has a declining trend. One of Europe's richest economies, Switzerland, takes the first place in Europe by the volume of the remittances sent. It covers $8 \%$ of the world total remittance flows (or 10 bln USD), while Germany gets 7\%, Luxembourg -- 4\%, France and Italy -- 2\% each (Danaj et al., 2018). Countries such as Spain and Israel also take the leading positions (De La Peña Esteban \& Peña-Miguel, 2018).

As it was mentioned above, remittances from individual countries in the recent years have demonstrated either an increase, or a decline. When it comes to increasing remittance flows, we can highlight such countries as Switzerland, Italy, Spain and France.

Remittance flows in different directions around the world. The routes through which they are sent are called remittance corridors. There are both national and international, and also remittance corridors within countries and regions. A typical feature of international 
corridors is that the flows are predominantly from advanced economies to the third world economies.

Specific continents use internal corridors. Asia has the largest corridor that carries up to three quarters of the total remittances flowing into Asian countries. Remittances in Europe flow mainly within the same regions (Strielkowski et al., 2018). The rest are financial injections from Asia and America. The most interesting situation is in Africa. European, Asian and also regional remittances account for about one third there. The largest recipients are North African countries, which receive up to $75 \%$ of the total remittances in the region.

The most important global remittance corridor is the US-Mexico corridor. According to the world statistics, remittance transfers within this corridor are up to 7.6 bln USD. From the overall perspective, the volume of transfers are also interesting in such corridors such Saudi Arabia - India with the value of roughly 3.6 bln USD, and Saudi Arabia-Pakistan with 1.8 bln USD. Regarding Europe, the largest flow of remittances goes from Germany to Turkey, it totals to 1.2 bln EUR.

At first glance, it may seem that geographical proximity of individual countries leads to simplification of transfers, but it is not always true. The key factors here are compatibility of the banking system or even presence of a common system. Both these factors can accelerate the money transfer and at the same time reduce charges behind such transactions.

\section{Remittance transfer}

There are many systems and methods for getting remittances from migrants to their recipients abroad. In general, however, we can talk about two basic types -- formal and informal ways of transfer. Formally, we include all those transfers that are controlled and regulated by the state and manifest themselves as actual remittances into actual statistics. Electronic money transfers, bank account transfers, electronic card transfers can be listed here.

The second group consists of the so-called informal ways of transfer. We cannot neglect these informal ways, because in some parts of the world informal transfers make up a significant share of the total remittances. However, the amount of money sent in this way is currently falling significantly because of the tightened control. There is also a possibility that informal channels can be used to finance terrorist activities. In any case, it it always the migrant choice, whether to choose formal or informal channels for transfer (Sirkeci \& Př́vara, 2017).

Each region has its own financial infrastructure with its specific financial instruments. The recipient chooses a financial instrument depending on the location of stay and duration of this stay. Another important determinant is the level of migrant's financial literacy. Good examples in this regard are payment cards, the use of which depends on the availability of ATMs and payment terminals in a region or specific locality. Most remittances use unofficial transfer paths because their use is many times easier than the official money journeys. The key advantage of the informal channels lies in their ability to adapt per specific clients. They are also associated with lower fees and are especially available in remote areas. However, we always need to keep in mind that informal transfers often imply the possibility of money laundering, terrorist organizations' support and so on. 


\section{MIGRANTS REMITTANCES: MICROECONOMIC}

\section{Remittances in V4 countries}

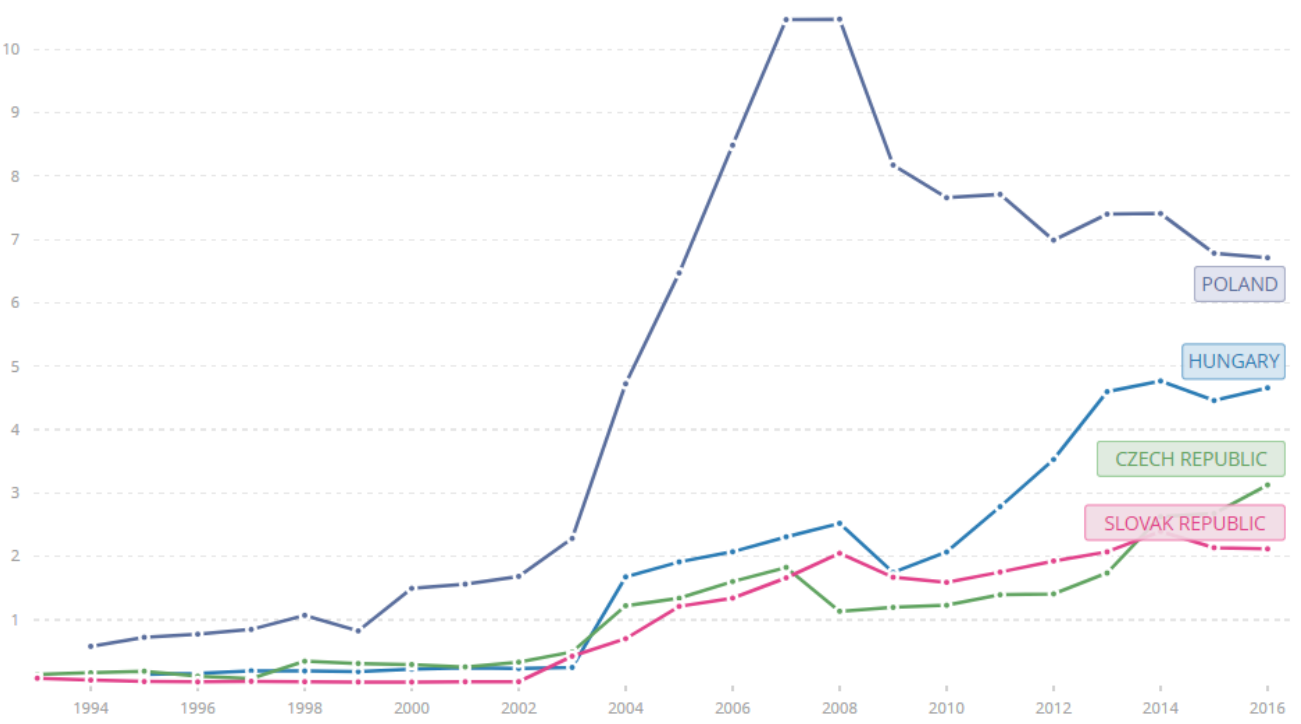

Figure 1 - Remittances delivered to the V4 countries (source: World Bank, 2019)

Our reference period is the period from 1994 to 2016. From the graph above we can see that for such countries as Slovakia, Czech Republic and Hungary, the period from 1993 to 2003 was characterized by the same tendencies in terms of the total received remittances volume. The total value of transactions was below 1 bln USD.

However, another tendency was observed in Poland. When comparing all V4 countries, we can see that the total volume of remittances received by Poland rose much more significantly than in neighbouring countries (Hudcovský et al., 2017).

A significant increase occurred at the turn of the millennium, in the period of 19992000, when Polish remittances rose from the level of 0.9 bln USD to 2.2. bln in 2003, while remittances to Slovakia, Czech Republic and Hungary only started to grow. In the next fivesix years Polish remittances rose to the level of almost 10 bln USD.

Geographically closest neighbors' of Poland -- Slovakia, Czech Republic and Hungary -- were only starting to experience an increase in 2003, and this increase until 2008 was really slight one. After that, for about two years remittances to these countries demonstrated a slight decline.

However, afterwards and up to 2016, there was again an increase in the accepted remittances, which is primarily related to the opening of borders between the countries in question. But again, the only exception among V4 countries was Poland. In 2007, the total value of Polish remittances rose above 10 bln. However, since that year, while remittances received by SR, Czech Republic and Hungary started to grow, in Poland, their volume, on the opposite, started to decline at a relatively fast pace, in particular, in 2012 their amount was 7 bln USD. From 2012 to 2016 we can observe slight fluctuations, we can actually call it a steady level of remittances. In 2016, the total received remittances in Poland amounted to less than 7 bln USD (Simionescu et al., 2018). 


\section{Conclusion}

Remittances represent a substantial capital resource for many countries, developing ones in particular. Their flows are normally lower than those of FDI; however, at the same time, they are higher than those of public development aid. In contrast to FDI, which decrease in the course of the global economic and financial crises, money transfers realised by emigrants continue to increase.

In some countries, financial aid sent by emigrants to their homeland reaches several tens of percent of GDP, which equals a considerable amount of money. That is the reason why this phenomenon is becoming the subject of interest for various international organisations, as well as for the scientific community worldwide. International organisations mostly emphasize on the positive impacts of remittances on the country of origin. This attitude is, however, questioned by many in scientific community.

In this article, we have attempted to describe and explain multiple aspects of remittances to expose the full extent of this phenomenon, as well as a variety of opinions and attitudes to it. Discussions on the determinants and effects of remittances on the country of migrant's origin have definitely not come to an end. There are still no clear answers to many questions asked in this regard. However, two things are certain:

a) Effective use of remittances in overcoming economic underdevelopment is preconditioned by both activation of recipients' households and by a suitable institutional environment in the country of migrant's origin.

b) Remittances cannot be regarded as a panacea for economic underdevelopment. In other words, economic policy of a developing country cannot be based solely on remittances.

We assume that in the following years, the interest of academic community in researching this issue will not fade. Directions of future research we forecast to be as follows (but not limited to): searching for the possibilities to decrease transaction costs connected with money transfer to the country of migrant's origin; analysis of the impact of remittances on the production structure of the economies characterized by high dependency on money transfers realised by emigrants.

\section{References:}

Adams, R. H., Page, J. (2005). Do International Migration and Remittances Reduce Poverty in Developing Countries? World Development, 33 (10): 1645-1669.

Amuedo-Dorantes, C., Pozo, S. (2006). Remittances as Insurance: Evidence from Mexican Immigrants. Journal of Population Economics, 19(2):227-35.

Azam, J.P., Gubert, F. (2005). Those in Kayes: The Impact of Remittances on their Recipients in Africa. Revue Economique, 56(6): 1331-1358.

Bourdet, Y., Falk, H. (2006). Emigrants Remittances and Dutch Disease in Cape Verde. International Economic Journal, 20(3): 267-284.

Buch, C.M., Kuckulenz, A. (2004). Worker Remittances and Capital Flows to Developing Countries, ZEW, Discussion Paper 4(31), ZEW, Mannheim.

Chauvet, L., Mesplé-Soms, S. (2007). Impact des financements internationaux sur les inégalités des pays en développement. Revue Economique, 58(3): 735-744.

Danaj, A., Lazányi, K., \& Bilan, Y. (2018). Perceptions and Implications of Immigration in France Economic, Social, Political and Cultural Perspectives. Economics \& Sociology, 11(3): 226247. 


\section{MIGRANTS REMITTANCES: MICROECONOMIC}

De La Peña Esteban, J. I., \& Peña-Miguel, N. (2018). Rethinking social welfare in Spain: a basic pension for everyone. EkonomskaIstraživanja, 31(1): 1737-1757.

Deskar-Škrbić, M., Drezgić, S., \& Šimović, H. (2018). Tax policy and labour market in Croatia: effects of tax wedge on employment. EkonomskaIstraživanja, 31(1): 1218-1227.

Docquier, F., Rapoport, H. (2003). Remittances and Inequality: A Dynamic Migration Model, IZA Discussion Paper 808, Institute for the Study of Labor, Bonn.

Ebeke, Ch., Le Goff, M. (2010). Impact des envois de fonds des migrants sur les inégalités de revenud ans les pays en développement. Revue économique 61(6):1051-1074.

Fajnzylber, P., López, H. (2008) (Eds). Remittances and development: lessons from Latin America. Washington, World Bank.

Görlich, D. et al. (2007). Explaining Labour Market Inactivity in Migrant-Sending Families: 15 Housework, Hammock, or Higher Education? Kiel Working Paper, \#1391, December.

Gupta, S., Pattillo, A., Wagh, S. (2009). Effect of Remittances on Poverty and Financial Development in Sub-Saharan Africa. World Development, 37: 104-115.

Hudcovský, M., Lábaj, M., \& Morvay, K. (2017). Employment Growth and Labour Elasticity in V4 Countries: Structural Decomposition Analysis. Prague Economic Papers, 26(4): 422-437.

IMF (2009). Balance of Payments and International Investment Position Manual. International Monetary Fund, Washington, D.C.

Konica, N., Filer, R. (2009). Albanian emigration: causes and consequences. South-Eastern Europe Journal of Economics, (1): 75-98.

Ratha, D. (2003). Workers' Remittances: an Important and Stable Source of External Development Finance. In Global Development Finance, World Bank.

Simionescu, M., Balcerzak, A. P., Bilan, Y., \& Kotásková, A. (2018). The impact of money on output in Czech Republic and Romania. Journal of Business Economics and Management, 19(1): 2041.

Sirkeci, I., \& Př́vara, A. (2017). Cost of Sending Remittances from the UK in the Aftermath of the Financial Crisis. Remittances Review, 2(1): 47-56.

Škuflić, L., \& Vučković, V. (2018). The effect of emigration on unemployment rates: the case of EU emigrant countries. Ekonomska Istraživanja, 31(1): 1826-1836.

Strielkowski, W., Rausser, G., Bilan, Y., \& Tsevukh, Y. (2018). Migrant remittances and their impact on the economic development of the Baltic States. Geographica Pannonica, 22.

Woodruff, C.M., Zeneto, R. (2001). Remittances and Microenterprises in Mexico. UCSD, Graduate school of International Relations and Pacific Studies Working Paper.

World Bank (2019). Migration and Remittances Factbook. World Bank Group, Washington, D.C.

Paper submitted

Paper accepted for publishing

Paper published online
29 August 2019

o2 November 2019

30 November 2019 